\title{
Research on the Status Quo and Mode of Freshman Admission Education under the Background of Complete Credit System
}

\author{
Qianyu Zhu \\ Faculty of Chinese Language and Culture \\ Guangdong University of Foreign Studies \\ Guangzhou, China
}

\author{
Jiang Li \\ Faculty of Chinese Language and Culture \\ Guangdong University of Foreign Studies \\ Guangzhou, China
}

\begin{abstract}
Freshman admission education is widely carried out in a high coverage, yet it is offered in a simple form and needs to further improve for better effect. In face of a complete credit system, this article acquires a group of freshman admission education data after making a survey on 2015 grade freshmen with different majors in a college, and builds models for correlation analysis to deeply analyze the efficiency of freshman admission education. The results show that the courses with a higher influence mainly include school rules and disciplines, student funding consultancy and instruction, occupational instruction and mental health education. The main countermeasures are proposed, including to innovate education philosophy, enrich education form, regulate education systems, optimize education carriers, renew education contents, optimize personalized education, introduce assessment system and exert joint efforts of school, so as to build a systematic, lasting and targeted freshman admission education system.
\end{abstract}

Keywords-freshman; freshman admission education; status quo; mode; policy suggestion

\section{INTRODUCTION}

International researches on freshman admission education show that researchers have already launched a series of researches on the concept, status quo, content and form relative to the admission education, through contrast, international scholars give concerns about the long term and systematic freshman admission education, for example, University of Adelaide and University of Queensland in Australia make a full arrangement of time to teach students "how to study in college"; Harvard University in the US offers a lot of systematic courses enabling students to receive a series of admission education as "how to listen to lectures", "how to ask questions", "how to participate in teaching practice", "how to finish final exam", "how to manage the time of my own", "how to make teamwork study and activities" and the more, besides, a credit system is introduced, only with the required credit obtained, can the follow-up courses be continued[1]. Most of Chinese scholars only make theoretical summaries in the necessity, philosophy, status quo, content and countermeasures relative to the freshman admission education, which, however, are in lack of supporting data, systematicness and targets, and what they stress more are the passive

Fund Project: This article is funded by the school-level youth joint fund project "Research on College Freshmen Learning Adaptability " (13s19) of Guangdong University of Foreign Studies in 2013 and the teaching and research project "Exploration on Status Quo and Mode of College Freshmen Admission Education" ( GWJY2015078 ) of Guangdong University of Foreign Studies "in $2015 .$. educational forms but less in students' individual education and efficiency, as a result, it is unavoidable to cause a disadvantageous condition as given above, besides, some even go against the freshmen adapted to a college life.

\section{BACKGROUND}

The status quo and problems existing in the freshman admission education found by scholars at home are mainly focused on lagging educational concept, programmed contents, out-of-date methods, single subjects and short term. Wang Yu (2008) points out that the freshman admission education is in lack of systematicness, target, consistency, interaction and efficiency, leading to defects in concept, form and the like[2]. Yang Zhiliang (2009) thinks that the freshman admission education is oversimplified in education form, difficult to stimulate students' enthusiasm, causing low effect in education dullness in form, out-of-date contents, it is far to meet the physical and mental development of students [3]. Xiao Xingyan and Zhang Zhiming (2010) propose that the freshman admission education shall keep humanities, the reform should focus on changes of educational concepts and stress personalized education; the educational methods should be renovated, combining online persuasion and offline instruction. In addition, though native scholars have summarized the freshman admission education in most colleges, yet the contents for admission education are scattered and unsystematic [4]. Wang Jiancheng (2009) raises that the modes for the freshman admission education shall be inclusive of discipline awareness education, mental health education, frustration education, study method education, interpersonal communication and perfect personality education, safety and law education, occupational career education and the like. In the meantime, he also suggests that the admission education should insist on a uniform education with a combination of diverse forms, college education and family education, special and individual counseling, negative and positive case education, instructor team perfection and so on so as to jointly improve the admission education[5]. Qu Yunjin and Jiang Song (2009) suggest that the measures to strengthen the efficiency of admission education should include: set a clear goal for freshman admission education, a goal involved in students' survival and development; innovate admission modes 
and rely on the prolonged educational period and assessment system to exert the overall educational forces of the college; regulate educational contents and optimize carriers of admission education, etc[6].

\section{RESEARCH DESCRIPTION}

Due to the few surveys and researches on the freshman admission education in the country, there are a series of problems to face such as lack of fully understanding the status quo and efficiency of the freshman admission education. In order to fully analyze the factors mentioned above, this article makes a survey on the efficiency of the freshman admission education in Guangdong University of Foreign Studies, main problems involved in include the following: (1) Adaptability of freshman under the background of complete credit system, which is taken as a reference index for the efficiency of the freshman admission education; (2) Individual characteristics of freshman: gender, household type and specialty; (3) Status quo and effect of freshman admission education, based on deep researches on the status quo, effect and improvement orientation of freshman admission education, we can raise policy advices for improving the freshman admission education.

\section{A. Research Framework}

Three purposes are designed for the research, first, unveil the status quo of freshmen of Guangdong University of Foreign Studies under the background of credit system, analyze the influence of characteristics of freshman to the efficiency of freshman admission education and disclose the efficiency and main problems of freshman admission education; second, under the background of complete credit system, analyze the contents of freshman admission education course and how to enrich the course forms and systems, and further build a long term and systematic mechanism; third, the reform of complete credit system is an opportunity and challenge, under the background of the complete credit system, to well do the freshman admission education is a practically instructive project for both colleges and students.

\section{B. Data Description}

A questionnaire was conducted on grade 2015 freshmen with different majors of Guangdong University of Foreign Studies in Mar 2016, main reason for the period selected for the survey was because the grade 2015 freshmen were enrolled in Sep 2015, after half a year adaptation and adjustment, the freshmen were basically able to correctly face the college life and distinguish the lives between college and senior school, and some thoughts and adjustments were made on the freshman admission education. During the survey, 800 questionnaires are delivered, 782 valid returned, the effectiveness rate is $97.75 \%$. Subject classification: literature: $21.48 \%$, economics: $32.99 \%$, management: $12.02 \%$, law: $5.37 \%$, education: $1.55 \%$, science: $24.29 \%$, art: $2.3 \%$; urban area: $60.61 \%$, rural area: $39.39 \%$; male: $32.48 \%$ and female: $67.52 \%$.

\section{Index Explanation}

During the research design, it is extremely important to select proper indices for the reliable conclusion, researches of scholars at home and abroad and survey data show, the freshman admission education is in lacks of systematicness, target, consistency, interaction and efficiency, leading to defects in concept, form and the like. Borrowing views of scholars at home and abroad, this author takes the influence of the complete credit system to the adaptability of freshman as a dependant variable to weigh the efficiency of freshman admission education, meanwhile, freshman's gender, household type (origin) and major are taken as control variables, and the contents of freshman admission education as explanatory variable to analyze the instruction for freshman admission (academic standards, college rules and disciplines, etc), courses or lectures to instruct college study methods and attitudes, career planning and occupation guide, mental health education, student funding consultancy and instruction, interpersonal communication and adaptability courses or guidance. Detailed variables and assignment are given in "Table I".

TABLE I. VARIABLE AND ASSIGNMENT

\begin{tabular}{|c|c|c|c|}
\hline Variable & & Name & Assignment \\
\hline $\begin{array}{ll}\text { Level } & \text { I } \\
\text { index } & \end{array}$ & Level II index & & \\
\hline $\begin{array}{l}\text { Explanato } \\
\text { ry } \\
\text { Variable }\end{array}$ & $\begin{array}{l}\text { Whether the complete } \\
\text { credit system influences } \\
\text { the freshman's } \\
\text { adaptability in study }\end{array}$ & $\mathrm{Y}$ & $\begin{array}{l}\text { The complete credit } \\
\text { system influences my } \\
\text { adaptability in study } \\
\text { A. } \quad \text { Completely } \\
\text { disagree. }=0 ; \\
\text { B. Mostly disagree.=1; } \\
\text { C. General.=2; } \\
\text { D. Mostly agree=3; } \\
\text { E. Completely agree =4; }\end{array}$ \\
\hline \multirow{3}{*}{$\begin{array}{l}\text { Control } \\
\text { Variable }\end{array}$} & Gender & $W_{11}$ & Gender: $\mathrm{A} . \mathrm{M}=0 \quad$ B. $\mathrm{F}=1$ \\
\hline & Student Origin & $x_{2}$ & $\begin{array}{l}\text { Household } \begin{array}{l}\text { Type: A. } \\
\text { Urban }=0 \\
=1\end{array} \\
\begin{array}{l}\text { B. Agricultural } \\
\end{array}\end{array}$ \\
\hline & Type of Major & 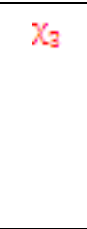 & $\begin{array}{l}\text { Major: A. Literature=0; } \\
\text { B. Economics=1; } \\
\text { C. Management=2; } \\
\text { D. Law=3. E. Pedagogy } \\
=4 ; \\
\text { F. Engineering }=5 ; \\
\text { G. } \text { Science }=6 ; \mathrm{H} \text {. Art=7 }\end{array}$ \\
\hline \multirow[t]{6}{*}{$\begin{array}{l}\text { Independe } \\
\text { nt } \\
\text { Variable }\end{array}$} & $\begin{array}{l}\text { Instruction for freshman } \\
\text { admission (academic } \\
\text { standards, college rules } \\
\text { and disciplines) }\end{array}$ & $\mathbb{F}_{1}$ & \multirow{6}{*}{$\begin{array}{l}\text { Do you think the } \\
\text { following courses that } \\
\text { you've learned in colleges } \\
\text { useable? Please the most } \\
\text { suitable } \\
\text { A. Not studied.=0; } \\
\text { B. Useless.=1; } \\
\text { C. Relatively useless. =2; } \\
\text { D. General =3; } \\
\text { E. Very useful=4; } \\
\text { F. Useful =5 }\end{array}$} \\
\hline & $\begin{array}{l}\text { courses or lectures to } \\
\text { instruct college study } \\
\text { methods and attitudes }\end{array}$ & $\mathbb{F}_{2}$ & \\
\hline & $\begin{array}{l}\text { career planning and } \\
\text { occupation guide }\end{array}$ & $\mathbb{F}_{\mathbb{Z}}$ & \\
\hline & Mental health education & $\mathbb{F}_{\text {a }}$ & \\
\hline & $\begin{array}{lr}\text { student } & \text { funding } \\
\text { consultancy } & \text { and } \\
\text { instruction } & \\
\end{array}$ & $\mathbb{F}_{5}$ & \\
\hline & $\begin{array}{l}\text { interpersonal } \\
\text { communication and } \\
\text { adaptability courses or } \\
\text { guidance }\end{array}$ & $\mathbb{F}_{6}$ & \\
\hline
\end{tabular}




\section{Survey Results}

There are many contents for the freshman admission education, yet the effect needs to further improve. The survey results show (refer to "Table II"), after registration, freshmen have received admission education contents of diverse aspects, $97.5 \%$ of whom received admission instruction, $94.5 \%$ participated in courses or lectures of college study methods and attitudes; $81.8 \%$ accesses to career planning and occupational instruction; $87.6 \%$ underwent mental health education; $74.2 \%$ acquired student funding consultancy and instruction; $81.5 \%$ participated in interpersonal communication and adaptability courses or counseling. However, as for the freshman admission education contents, only $25.3 \%-36.6 \%$ thought it relatively useful or useful; $14.3 \%-31.6 \%$ thought it useless or relatively useless, which prove that though the freshman admission education is valued with a high coverage, focusing on the diversity of educational contents and forms, yet, the efficiency is still to be improved.

TABLE II. DATA OF STATUS QUO OF FRESHMAN ADMISSION EDUCATION

\begin{tabular}{|c|c|c|c|c|c|c|}
\hline & \multirow{2}{*}{$\begin{array}{c}\text { Not } \\
\text { Rec } \\
\text { eive } \\
\text { d }\end{array}$} & \multicolumn{5}{|c|}{ Received } \\
\hline & & $\begin{array}{c}\text { Usel } \\
\text { ess }\end{array}$ & $\begin{array}{c}\text { Relative } \\
\text { ly } \\
\text { Useless }\end{array}$ & General & $\begin{array}{l}\text { Relative } \\
\text { ly } \\
\text { Useful }\end{array}$ & Useful \\
\hline $\begin{array}{l}\text { Instruction } \\
\text { for } \\
\text { freshman } \\
\text { admission } \\
\text { (academic } \\
\text { standards, } \\
\text { college } \\
\text { rules and } \\
\text { disciplines) }\end{array}$ & $\begin{array}{l}2.5 \\
\%\end{array}$ & $\begin{array}{l}11.4 \\
\%\end{array}$ & $20.2 \%$ & $40.7 \%$ & $18.6 \%$ & $6.6 \%$ \\
\hline $\begin{array}{ll}\text { Courses } & \text { or } \\
\text { lectures } & \text { to } \\
\text { instruct } & \\
\text { college } & \\
\text { study } & \\
\text { methods } & \\
\text { and } & \\
\text { attitudes } & \end{array}$ & $\begin{array}{l}5.5 \\
\%\end{array}$ & $\begin{array}{l}8.1 \\
\%\end{array}$ & $12.4 \%$ & $40.2 \%$ & $24.6 \%$ & $9.2 \%$ \\
\hline $\begin{array}{l}\text { Career } \\
\text { planning } \\
\text { and } \\
\text { occupation } \\
\text { guide }\end{array}$ & $\begin{array}{l}18.2 \\
\%\end{array}$ & $\begin{array}{l}6.8 \\
\%\end{array}$ & $7.5 \%$ & $31.2 \%$ & $24.9 \%$ & $11.4 \%$ \\
\hline $\begin{array}{l}\text { Mental } \\
\text { health } \\
\text { education }\end{array}$ & $\begin{array}{l}12.4 \\
\%\end{array}$ & $\begin{array}{l}6.6 \\
\%\end{array}$ & $15.9 \%$ & $32.4 \%$ & $25.4 \%$ & $7.3 \%$ \\
\hline $\begin{array}{l}\text { Student } \\
\text { funding } \\
\text { consultancy } \\
\text { and } \\
\text { instruction }\end{array}$ & $\begin{array}{l}25.8 \\
\%\end{array}$ & $\begin{array}{l}6.9 \\
\%\end{array}$ & $12.0 \%$ & $30.0 \%$ & $19.0 \%$ & $6.3 \%$ \\
\hline $\begin{array}{l}\text { Interperson } \\
\text { al } \\
\text { communicat } \\
\text { ion and } \\
\text { adaptability } \\
\text { courses or } \\
\text { guidance }\end{array}$ & $\begin{array}{l}18.5 \\
\%\end{array}$ & $\begin{array}{l}5.2 \\
\%\end{array}$ & $10.5 \%$ & $29.2 \%$ & $26.1 \%$ & $10.5 \%$ \\
\hline
\end{tabular}

\section{EMPIRICAL RESEARCHES AND RESULTS ANALYSIS}

\section{A. Model Design}

The model takes the efficiency of freshman admission education as a dependant variable, freshman's gender, household type (origin) and major as control variables, and the freshman admission education instruction (as academic standards, college rules and disciplines, etc), courses or lectures to instruct college study methods and attitudes, career planning and occupation guide, mental health education, student funding consultancy and instruction, interpersonal communication and adaptability courses as interdependent variable, so as to build a regression model, shown as follows:

$$
\mathrm{Y}=\mathrm{a}_{0}+\sum_{\mathrm{i}=1}^{\mathrm{n}} \mathrm{a}_{\mathrm{i}} \mathrm{X}_{\mathrm{i}}+\sum_{\mathrm{i}=1}^{\mathrm{n}} \beta_{\mathrm{j}} \mathrm{F}_{\mathrm{j}}+\phi
$$

Of which, $\mathrm{Y}$ refers to efficiency index of freshman admission education, intercept, regression coefficient of control variable, control variable, regression coefficient of variables, variable factors.

\section{B. Analysis of Empirical Results}

A regression analysis is made via Eviews software to get an estimated result for the model as shown in "Table III".

TABLE III. INDICES INFLUENCING THE EFFICIENCY OF FRESHMAN ADMISSION EDUCATION

\begin{tabular}{|c|c|c|}
\hline Variable & Influential Indices & Adaptability \\
\hline \multirow{3}{*}{$\begin{array}{l}\text { Control } \\
\text { Variable }\end{array}$} & Gender & $0.444964 * * *$ \\
\hline & Urban area or rural area & $0.274885 * *$ \\
\hline & Type of Major & $0.089119 * * *$ \\
\hline \multirow{6}{*}{$\begin{array}{l}\text { Independent } \\
\text { Variable }\end{array}$} & $\begin{array}{l}\text { Instruction for freshman admission } \\
\text { (academic standards, college rules } \\
\text { and disciplines) }\end{array}$ & $-0.254254 * * *$ \\
\hline & $\begin{array}{l}\text { Courses or lectures to instruct } \\
\text { college study methods and attitudes }\end{array}$ & -0.013339 \\
\hline & $\begin{array}{l}\text { Career planning and occupation } \\
\text { guide }\end{array}$ & $-0.165263^{* *}$ \\
\hline & Mental health education & $-0.172281 * *$ \\
\hline & $\begin{array}{l}\text { Student funding consultancy and } \\
\text { instruction }\end{array}$ & $-0.269323^{* * *}$ \\
\hline & $\begin{array}{l}\text { Interpersonal communication and } \\
\text { adaptability courses or guidance }\end{array}$ & -0.103761 \\
\hline
\end{tabular}

1) Analysis of variable influence control: Under the background of complete credit system, the influences of freshman's gender, origin, urban area or rural area and major to the adaptability are significant, so this research has taken the factors mentioned above into full consideration, in order to analyze whether individual characteristics of freshman have influence to the efficiency of freshman admission education, it is introduced to the model as control variable for consideration. 
Statistical results show, it is significant with the significance level of $1 \%$; under the background of complete credit system, factors as gender and major have a higher influence to the freshman's adaptability. The adaptability of boy students is higher than that of girl students, 0.4 times of them. The adaptability of students majoring in literature and history is higher than that of students majoring in science, for the difficulty of major of literature and history is lower than that of major of science, so the pressure of freshmen in study is less, except the study, they may participate in other afterschool activities so as to enrich the college life. Besides, Guangdong University of Foreign Studies is a university of liberal arts, and most majors are involved in linguistics and economic management, so the freshmen have a higher adaptability. Yet whether the students are from urban areas or rural areas is significant with the significance level of $5 \%$, because most students of Guangdong University of Foreign Studies come from towns, besides, most of senior high school students are resident students, who are much easier to adapt to the college life and study mode.

2) Analysis of dependent variable influence: The statistic analysis results show, with the significance level of $1 \%$, on the background of complete credit system, the freshman admission education instruction (as academic standards, college rules and disciplines, etc), student funding consultancy and instruction courses have a big help to freshman's adaptability, researches of scholars at home and abroad show, the freshman's adaptability is highly influenced by family economic environment and college environment, which has been proved in the survey. During the admission education, the courses of college rules and disciplines and training of student funding may help students further know the college environment and also help students from poor families grasp financial support policies of colleges, according to the conditions of their own, the students may select a funding mode suitable for them so as to devote themselves to the study and improve the adaptability to the college.

With the significance level of $5 \%$, within the freshman admission education system, career planning and occupational instruction course and mental health education course have a certain help to freshman's adaptability. Questionnaire surveys show, $32.4 \%$ of freshmen have their adaptability in study influenced due to the uncertainty to the future, $27.1 \%$ of freshmen have certain in-adaptation in study due to the higher difference in their knowledge before and after admission, the complete credit system makes it more free to select courses, $74.94 \%$ of students think it a push to their passion in study. During the freshman admission education, the career planning and occupational instruction course enable them to implement a career planning suitable and carry it out step by step, our university also sets Occupational Career Planning for College Students and achieves a lot through education from grade I to grade IV, and $67.5 \%$ of students think the career planning useful for them. $65.1 \%$ of students have received mental health education, thinking it useful; it proves that mental health education in colleges has made a certain achievements. In addition, all freshmen are required to receive surveys on mental health; there are still $12.4 \%$ of freshmen who show receiving no mental health education. Therefore, colleges should improve the quality of mental health education course, gradually raising students' understanding of mental health education, meanwhile, set mental health committee and peer student cadres for mental health support in each class, so as to enhance the students' mental health quality through a pointarea drive.

However, during the freshman admission education, courses or lectures to instruct college study methods and attitudes and course or counseling courses relative to interpersonal communication and adaptability have no big help to freshman's adaptability, which is not significant with the significance level of $5 \%$. Survey data show, for the maximum factor to the freshman's adaptability in study, the study method and attitude have a general effect, hard to help freshmen make sure of study goals, correct study attitude, increase study interest for efficient study. For most freshmen are adult, whose characteristics have been formed and difficult to change, though the interpersonal communication may influence freshman's adaptability, yet the over-theorization of admission education courses and short term courses make it difficult to change freshmen's characters, so the interpersonal communication course set in the freshman admission education is unable to work.

3) Conclusion: Empirical analysis shows that the education courses with higher efficiency on freshman admission education mainly include academic standards, college rules and disciplines, student funding consultancy and instruction, career instruction and mental health education. It gets benefits from the systematic and long term education course system and teaching step by step in different grades created in the freshman admission education. Meanwhile, multiple measures can be taken together, through standard courses, colleges may offer perfect service, class tutors and assistants may teach practical experience via negotiation and collective teaching so as to push the freshman admission education. Though the complete credit system brings more chances to students to select courses and enhance their passion in study, yet the admission education courses for study instruction is still imperfect, as a result, it is difficult to meet new study goals and methods under the complete credit system, meanwhile, original administrative classes are cancelled, and each class will have different students, which expands and highlights the interpersonal circle, according to the interpersonal communication courses and consultancy service, colleges should offer students more friendly study atmosphere in campus.

\section{COUNTERMEASURES}

\section{A. Innovate Education Philosophy and Enrich Education Form}

Borrow the philosophy of foreign admission education, change the centralized short term learning mode before and attempt to build a long term and systematic admission education system. Enrich the educational forms through systematic courses, personal consultancy, peer counseling, students' activities and so on, improve the forms and ways for freshmen to receive the admission education, and the short term centralized training can make students master and be 
familiar with college rules and systems, college environment and resources, funding system to students, so that the students may adapt to the environment as soon as possible, remove the factors that may affect the adaptability in study and start their life in colleges.

\section{B. Regulate Education Systems and Optimize Education Carriers}

For most colleges and universities in the country carry out the freshman admission education in lacks of systematicness in form, target in content, consistency in time, interaction in method and efficiency in form, so they should value the freshman admission education, regulate the education system and optimize education carriers through setting regular courses, personalized consultancy and collective counseling by colleges' functional departments, holding freshmenschoolfellow exchanges, lectures by special teachers for instruction as well as all kinds of social practices. In the meantime, we should insist on the combination of uniform education and diverse forms of education, interaction between college and families, team counseling and personalized consultancy, positive and negative case education, counselor's heart to heart talk system, and create a free study atmosphere for freshmen under the complete credit system so as to build a perfect freshman admission education system. In addition, through the online persuasion and offline instruction, colleges may introduce internationally advanced admission education course so as to enable freshmen to receive different admission education.

\section{Renew Education Contents and Optimize Personalized Education}

Main contents of freshman admission education shall be in inclusive of instruction for freshman admission (academic standards, college rules and disciplines, etc), courses or lectures to instruct college study methods and attitudes, career planning and occupation guide, mental health education, student funding consultancy and instruction, interpersonal communication and adaptability courses or guidance. The freshman admission education is never kept unchanged, it shall persist in the integrity of special counseling and personalized consultancy, closely tracking students' characteristics and demands, gradually expand the admission education contents, introduce internationally advanced philosophies and courses, and renovate previous theory-based admission education course system. Through the advanced admission education contents that are provided and will affect the life of freshmen such as study instruction education, frustration education, healthy personality education, college spirit education and so on, colleges should gradually build a freshman admission education system characterized of special target, timeliness, systematicness and lasting, where the personalized demands are much valued.

\section{Introduce Assessment System and Exert Joint Efforts of Colleges}

The freshman admission education system in most colleges and universities belongs to a rough theory education, which is generally completed by a teacher teaching lecturers within a week before beginning of a new term, disregarding the joint efforts of colleges, the society and families to mobilize social resources, nor care the teaching nature. Therefore, it needs to introduce an assessment system and inspect and understand the admission education effect through after-class survey, after school interviews, even regular course check system as well as student activity matches. Meanwhile, the complete credit system can be used to improve the freshman admission education quality, and the credit acquired can be a tool to evaluate the attendance and effect of admission education. Relying on college's attentions, active cooperation by functional departments, whole-course counseling from special teachers and coordination of counselors as well as students' whole-course participation, a scientific and systematic freshman admission education system will come into being.

\section{CONCLUSION}

From these, we can see that current college freshman admission education has a high popularity and a extensive content, but it is mostly the passive education for group and not the individual education and effective education for students, which is easy to lead to lack of long-term and systematic education, and brings little function for improvement of the adaptability of college freshmen. Under the background of absolute credit system, college students must adapt to more complex environment, and the survey results show that colleges and universities can develop a systematic education in the school discipline, student funding advice and guidance, vocational guidance courses, mental health education and other aspects. We can innovate the educational concept, enrich the educational form, standardize the educational system, optimize the educational carrier, improve the educational content, optimize the personality education, introduce the assessment system and play the resultant force of school, to further improve and build the targeted and long-term freshman admission education system, and to better improve the adaptability of freshmen.

\section{REFERENCES}

[1] Hong Yun, Lyu Xiaoqing, Discussion on Freshman Admission Education [J]. Coastal Enterprises and Science \& Technology. 2007(10).191-193.

[2] Wang Yu, Research on Status Quo and Countermeasures of Freshman Admission Education [J]. Business Economy. 2008(10).124-125.

[3] Yang Zhiliang, Discussion on Problems and Countermeasures of Current Freshman Admission Education [J]. Journal of Chifeng University (Natural Science Edition). 2009(11).196-197.

[4] Xiao Xingyan, Zhang Zhiming, Reform and Innovation of Freshman Admission Education [J]. Journal of Shaoguan University · Natural Science. 2010(6).124-128.

[5] Wang Jiancheng, Thoughts of Freshman Admission Education Modes $[\mathrm{J}]$. Journal of Shandong Youth Administrative Cadres College. 2009(9).49-51.

[6] Qu Yunjin, Jiang Song, Research on Efficiency of Freshman Admission Education [J]. Journal of Higher Education Management. 2009(11).8084 